\title{
Infection by Botryodiplodia theobromae pat. in relation to phenol and calcium content in tubers of market samples (two) of Ipomea batatas L.
}

\begin{abstract}
This study investigated infection and weight loss in market samples of Ipomea batatas in relation to their phenol and calcium content which confer resistance to infection in plants. Tubers were incubated for seven days only with Botryodiplodia theobromae (because of rapid deterioration) in a CRD experiment of two treatments (the two markets, Lagos and Abeokuta) and seven replicates. Infection was $400 \%$ higher in the Lagos tubers, but $53.11 \%$ weight loss in the Abeokuta tubers was significantly higher than the 41.765 in the Lagos tubers. Six of the seven mineral contents analyzed were not different in the two treatments. Their mean values in $\mathrm{mg} / 100 \mathrm{~g}$ dry matter were $\mathrm{Ca} 12.84, \mathrm{Mg} 22.27, \mathrm{k} 414.27, \mathrm{Fe} 8.1$, N 1156.67 and P 54.59. S content of $620.33 \mathrm{mg} / 100 \mathrm{~g} \mathrm{dm}$ of Lagos tubers was significantly higher than the $614.67 \mathrm{mg} / 100 \mathrm{~g} \mathrm{dm}$ of Abeokuta tubers. Phenol content of $264.86 \mathrm{mg} / 100 \mathrm{~g}$ $\mathrm{dm}$ (Lagos tubers) and $261.28 \mathrm{mg} / 100 \mathrm{~g} \mathrm{dm}$ (Abeokuta tubers) were comparable /similar. There were no significant correlations in calcium and phenol content with infection and weight loss, but there was a negative significant correlation $(r=-0.8514)$ between tuber nitrogen and weight loss. Calcium fertilization to upgrade sweet potato tuber calcium content to optimal level in reduction of infection/weight loss by B. theobromae as well as other fungal rot pathogens is important in Nigeria. This may upgrade tuber phenolic compounds as calcium is implicated in phenolic compounds synthesis. Nitrogen content may be balanced with other minerals in sweet potato production as the negative correlation indicates that increase in Nitrogen will reduce tuber weight loss.
\end{abstract}

Volume 8 Issue 6 - 2018

\section{Otusanya MO \\ Department of Crop Protection, College of Plant Science and Crop production, Federal University of Agriculture Abeokuta,} Nigeria

Correspondence: Otusanya MO, Department of Crop Protection, College of Plant Science and Crop production, Federal University of Agriculture Abeokuta, Nigeria, Email otusanvaoluleke@gmail.com

Received: July 16, 2018| Published: December 05, 2018

\section{Introduction}

Ipomea batatas $L$. (sweet potato) is a staple in Nigeria where the edible roots provide food security and income for producers. ${ }^{1}$ A major constraint to realizing the maximum potential of the crop is the short shelf life due to easy/quick deterioration coupled with inadequate storage conditions. Shelf life of storage organs such as sweet potato root tuber depends on varietal resistance (to rots), as well as tuber quality established by disease management inputs in the field and after harvest. Phenolic compounds are implicated in resistance of crops to infection. ${ }^{2}$ Calcium soil amendment or foliar sprays and calcium fertilization of growing plants have improved/increased resistance to fungal rot pathogens. Calcium carbonate fertilization along with NPK in two improved varieties of Dioscorea (D. rotundata TDr 131 and $D$. alata TDa 92-2), reduced both infection and weight loss by Botryodiplodia theobromae (Otusanya et al., 2016). Internal brown spot and sub-apical necrosis of irish potatoes (Solanum tuberosum) were reduced with calcium. ${ }^{3}$ Increased resistance to Erwinia carotouora soft rot in Solanum tuberosum (irish potato) tubers was achieved by calcium fertilization of the growing plant and spraying/ immersion of the tubers in calcium solution., ${ }^{4,5}$ There is paucity in literature on any form of calcium fertilization of sweet potatoes in Nigeria. This study was carried out to ascertain calcium and phenol content of sweet potato tubers in relation to infection/weight loss by Botryodiplodia theobromae Pat, an important rot pathogen of Ipomea batatas $L$ in Nigeria.

\section{Materials and methods}

\section{Sourcing of tubers}

Tubers of Ipomea batatas for this study were sourced from two major markets, in two major towns in Ogun and Lagos states, Nigeria. Those from Ogun state were purchased from Iberekodo market in Abeokuta, and those from Lagos state were purchased from Agege market in the city of Lagos.

\section{Infection and weight loss experiment}

The infection and weight loss experiment was arranged in CRD (complete randomized design) with two treatments, that is the two markets and seven replications. The rot pathogen Botryodiplodia theobromae was isolated from a partially rotted tuber of Ipomea batatas from Omida market in Abeokuta town. A pure 10-day old culture of it was prepared by spore transfer on to potato dextrose agar using standard methods. ${ }^{6}$ Weights of tubers for the experiments were measured with a top loading mettler balance. Inoculation of tubers was carried out within an Inoculation Hood structure in the Crop Protection Laboratory of the Department of Crop Protection, COLPLANT Building (College of Plant Science and Crop Production), Federal University of Agriculture (FUNAAB), Abeokuta. Two cork borers of $4 \mathrm{~mm}$ diameter, scalpel and forceps were surface-sterilized. This was by dipping each in $70 \%$ methylated spirit and flaming until red hot over a lighted spirit flame bottle, and cooling each, slanted against another cork borer. The inoculation site on each tuber was swabbed with cotton wool dipped in $90 \%$ ethanol. After this, one surface-sterilized cork borer was pushed into the inoculation site on the tuber to a depth of about $20 \mathrm{~mm}$. The cut tissue was lifted out with the scalpel and forceps. A $4 \mathrm{~mm}$ agar (potato dextrose agar) disc of the pure culture of $B$. theobromae was lifted from the culture dish with the second surface-sterilized $4 \mathrm{~mm}$ cork-borer, and placed in the hole made in the tuber. The cut out tissue was then replaced and the site sealed with vaseline (petroleum jelly). The inoculated tubers 
were kept in a raised, wooden netted yam storage structure in the COLPLANT Screen house for 7 days. After this period, each tuber weight was measured again. Vaseline on tubers was cleared away with spatula and cotton wool. Each tuber was then cut open through the inoculation site with a sharp knife. Infected tissue from the two halves of the tuber was cut away with a scalpel on to a pre-weighed open petri-dish. Infected tissue weight was measured with an electronic balance. Percent weight loss was calculated with the formula:

$$
\% \text { Weight } \operatorname{loss}(\mathrm{Y})=\left(\frac{\mathrm{A}-\mathrm{B}}{\mathrm{A}}\right) 100,
$$

Where $\mathrm{A}$ and $\mathrm{B}$ are weight of the tuber at the beginning and at the end of the experiment respectively. Percent infection was determined with the formulae:

$$
\% \text { Infection }=\left(\frac{\mathrm{C}}{\mathrm{A}}\right) 100,
$$

Where $\mathrm{C}$ is the corrected weight of the infected tissue and $\mathrm{A}$ is the weight of the tuber at the beginning of the experiment. $\mathrm{C}$ is calculated with the formula

$$
\mathrm{C}=\frac{100 \mathrm{X}}{100-\mathrm{Y}} \text { (Otusanya and Jeger, 1994) }
$$

Where $\mathrm{X}$ is weight of infected tissue and $\mathrm{Y}$ is the percentage weight loss.

\section{Determination of phenol and mineral content of tubers}

Tubers from the two markets were washed in tap water, dried under a low-speed fan and sliced into thin chips in labelled trays. The chips were dried on raised wooden structures (under shade) in the COLPLANT screen house, FUNAAB, for 2 to 3 days. After this, the chips were ground to powder with a Saisho 4-speed blender. Samples were in quadruplicate. The milled samples were analyzed for phenol content, Calcium, Nitrogen, Phosphorus, Potassium, Iron, Magnesium and Sulphur content with standard methods of the A.O.A.C. ${ }^{7}$ Analysis of the samples was in the Biological Sciences Tetfund Laboratory, Department of Biological Sciences and the Biotechnology Centre, FUNAAB, Abeokuta.

Table 2 Mineral content and phenol (mg/l00g dry matter) in white-fleshed Ipomea batatas from Ogun and Lagos state in South West, Nigeria

\begin{tabular}{lllllllll}
\hline Source of Ipomea batatas & Calcium & Phenol & $\mathbf{M g}$ & $\mathbf{K}$ & $\mathbf{F e}$ & $\mathbf{N}$ & $\mathbf{P}$ & $\mathbf{S}$ \\
\hline IB ABEOKUTA & $13.15 \mathrm{a}$ & $261.28 \mathrm{a}$ & $22.5 \mathrm{la}$ & $413.73 \mathrm{a}$ & $8.17 \mathrm{a}$ & $1153.67 \mathrm{a}$ & $54.13 \mathrm{a}$ & $614.67 \mathrm{~b}$ \\
IB LAGOS & $12.53 \mathrm{a}$ & $264.86 \mathrm{a}$ & $22.03 \mathrm{a}$ & $414.80 \mathrm{a}$ & $8.02 \mathrm{a}$ & $1159.67 \mathrm{a}$ & $55.04 \mathrm{a}$ & $620.33 \mathrm{a}$ \\
\hline
\end{tabular}

Means in a column followed by the same letter are not significantly different at $\mathrm{P} \leq 0.05$ (Tukey's HSD test)

\section{Correlation of mineral content, infection and weight} loss

The only significant correlation was a negative one between Nitrogen and weight loss. The value is $r=-0.8514$.

\section{Discussion}

The tubers sourced from Lagos city had significantly higher infection which was over $400 \%$ of that of the tubers from Abeokuta city. Weight loss in the Lagos tubers was however about $21 \%$ less than that in the Abeokuta tubers. This is a marked reduction in the tuber quality in just 7 days. The incubation experiment was not longer than this period because of the fast deterioration of the tubers. Six of the seven minerals analyzed namely Calcium, Magnesium, Potassium, Iron, Nitrogen and Phosphorus were not significantly different in tubers from the two towns. But Sulphur content in the Lagos tubers was higher than that of the Abeokuta tubers. Phenol

\section{Data Analysis}

Data were subjected to ANOVA (analysis of variance) after appropriate transformation of percent data. Means were separated with Tukey's (HSD) test.

\section{Results}

\section{Infection and weight loss experiment}

Infection was significantly higher in the potatoes from Lagos with the value $19.27 \%$ than those from Abeokuta town, which was $4.3 \%$ (Table 1). Weight loss in the 7days period was high and significantly higher in the tubers from Abeokuta with the value 53.11\% than those from Lagos which had weight loss of $41.76 \%$ (Table 1).

Table I Infection and weight loss in tubers of Ipomea batatas (IB) by Botydiplodia theobromae after 7 days incubation

\begin{tabular}{lll}
\hline Source of Ipomea batatas tubers & $\begin{array}{l}\text { Infections } \\
(\%)\end{array}$ & $\begin{array}{l}\text { Weight } \\
(\%)\end{array}$ \\
\hline IB ABEOKUTA & $4.30 \mathrm{~b}$ & $53.1 \mathrm{la}$ \\
IB (LAGOS) & $19.27 \mathrm{a}$ & $41.76 \mathrm{~b}$ \\
\hline
\end{tabular}

Means in a column followed by the same letter are not significantly different at $\mathrm{P} \leq 0.05$ (Tukey's HSD test)

\section{Comparison of mineral content}

All minerals analyzed except for sulphur were not significantly different in the tubers from the two locations. Nitrogen had a mean of $1156.67 \mathrm{mg} / 100 \mathrm{gdm}$ (Table 2). The mean values for the others are $12.84 \mathrm{mg} / 100 \mathrm{gdm}$ for calcium, $22.27 \mathrm{mg} / 100 \mathrm{gdm}$ for Magnesium, $414.27 \mathrm{mg} / 100 \mathrm{gdm}$ for potassium, $8.10 \mathrm{mg} / 100 \mathrm{gdm}$ for iron and 54.59 $\mathrm{mg} / 100 \mathrm{gdm}$ for phosphorus. Sulphur was significantly higher in the tubers from Lagos, that is $620.33 \mathrm{mg} / 100 \mathrm{gdm}$, than those from Abeokuta which had $614.67 \mathrm{mg} / 100 \mathrm{gdm}$. Phenol content in tubers from the two locations was also not significantly different from one another, and the mean value is $263.07 \mathrm{mg} / 100 \mathrm{gdm}$ (Table 2). content was also not different in tubers from the two towns with an average of $263.07 \mathrm{mg} / 100 \mathrm{gdm}$. Tubers from Lagos had numerically higher phenol of $264.86 \mathrm{mg} / 100 \mathrm{gdm}$ than those from Abeokuta with $261.28 \mathrm{mg} / 100 \mathrm{gdm}$. The lower infection in the Abeokuta tubers may be due to other phenolic compounds and not phenol. Calcium content in tubers from both towns was also not different. Increase in potato (Solanum tuberosum) tuber calcium content and apple fruit calcium content, have been reported to be directly related to increase in resistance to bacterial and fungal infection (Mcguire and Kelman $1984 ;{ }^{8}$ Increase in bean (Phaseolus species) tissue calcium content from $1.6 \%$ to $3.4 \%$ greatly reduced Erwinia carotovora infection. ${ }^{9}$ Immersion of potato, Solanum tuberosum tubers in calcium solution resulted in higher tissue integrity. ${ }^{5}$ Calcium fertilization $\left(\mathrm{CaCO}_{3}\right.$ and NPK) of two varieties of Dioscoreaspecies namely D. rotundata TDr 131 and D. alata TDa 92-2, reduced both infection and weight loss by Botryodiplodia theobromae. ${ }^{10}$ Calcium fertilization in sweet potato production is not yet practiced in Nigeria. This study underscores the 
high losses in short periods in sweet potatoes, in Nigeria, where it may easily become not only a food security but also a high income generating commodity. There is need to establish calcium content in local varieties of Ipomea batatas tubers that may be considered optimal for appropriate storage and of the standard export quality in Nigeria. Calcium fertilization may upgrade phenolics with their antimicrobial potential in Ipomea batatas tubers for better tuber quality as calcium has been directly implicated in the synthesis of phenolic compounds. ${ }^{11,12}$ There was high significant negative correlation $(\mathrm{r}=-0.8514)$ between potato tuber nitrogen and weight loss after incubation with the rot pathogen $B$. theobromae in this study. This suggests that improvement in sweet potato production may be achieved by systematic research whereby nitrogen uptake of the tubers is increased and balanced also (balanced mineral nutrition) with other essential minerals for higher tuber quality.

\section{Acknowledgments}

None.

\section{Conflicts of interest}

The authors declared there is no conflicts of interest.

\section{References}

1. Ukpabi UJ. Roots and Tubers in Nigeria as Sources of Industrial Raw Materials. In: Nigeria Agro Raw Materials Development: Some Industrial Crops and Salient Issues. Onwualu, Obasi, Ukpabi et al editors. RMDRC Publications, Abuja: 2009;1:1-19.

2. Dube HC. Modern Plant Pathology. 2nd edition. Saraswati Purohit, Jodhpur: 2014; 576 p.
3. Tzeng K, Kelman A, Simmons K. et al. Relationship of calcium nutrition to internal brown spot of potato tubers and sub-apical necrosis of sprouts. American Potato Journal. 1986;63(20):87-97.

4. McGuire RG, Kelman A. Reduced severity of Erwinia soft rot in potato tubers with increased calcium content. The American Phytopathological Society. 1984;74(10):1250-1256.

5. Ahme L, Proton F, Fumebo T. Comparison of drying kinetics and texture effects of two calcium pre-treatments before micro-wave assisted dehydration of apples and potato. International journal of food science and technology. 2003;38(4):411-420.

6. CMI. Plant pathologist's pocket book. 2nd ed. The Cambrian New Ltd, Queen Street, Aberystwth: 1968.

7. Association of Official Analytical Chemists (A.O.A.C.) Official methods of Analysis 15th ed. Washington DC: 1990.

8. Sotriropoulos TE, Therios IN, Dimassi KN. Et al. Effects of application of a complex and N-Ca fertilizer on leaf and fruit nutrient concentrations and some fruit quality parameters in two apple cultivars. Horticultural science (Prague). 2005;32(1):9-16.

9. Eastwood GW. Calcium's Role in Plant Nutrition. Fluid Journal. 2002;3.

10. Otusanya MO, Enikuomehin O, Popoola A, et al. Effects of calcium fertilization on the susceptibility of Dioscorea species to the yam storage pathogens Aspergillus niger van Tiegh and Botryodiplodia theobromae pat. J Plant Physiol Pathol. 2016;41(3).

11. Singh RS. Introduction to Principle of Plant Pathology. 4th ed. Oxford \& IBH Publishing Company Pvt. Ltd. India: 2002;402 p.

12. Castaneda P, Perez LM. Calcium ions promote the response of citrus lemon against fungal elicitors in wounding. Photochemistry. 1996;42(3):595-598. 